\title{
HERMENEUTICKÉ ČTENÍ DĚL JIŘíHO LEVÉHO
}

\author{
TOMÁŠ SVOBODA
}

\begin{abstract}
At first glance, the work of Jiř́ Levý shows many similarities with the thoughts and concepts of the (neo)hermeneutic approach within Translation Studies (TS). This observation is shared by many and it became part of the scientific discourse. At second glance, however, a number of discrepancies between the two approaches become apparent, some of which are substantial. Obviously, Jiří Levý himself cannot be regarded a member of the neohermeneutic branch of TS for the reasons of chronology, since he died some 10 years prior to the establishment of this branch, which took place in the late 1970s and early 1980s. When comparing his concepts with those of the hermeneutic approach, the following picture emerges: There are instances of perfectly matching concepts, there are those of profound mismatch, and, eventually a grey area in between.

Apart from the specific methodological feature, where the two approaches (the one of Levý and that of Hermeneutics) both use extensive examples to illustrate theoretical stances, there are Translation Studies and Literary Theory terms and concepts, the meaning of which they share. These terms and concepts are the following: the text's value, which surpasses the simple addition of its discrete parts, Levýs idea of perception on the one hand and the hermeneutical circle on the other, creativity and other rqualities required on the part of the translator, equality of the aesthetic effect. The two approaches also tend to show a partial overlap, when it comes to the applicability of translation theory, the language and style of theoretical works, the focus on the individual (recipient, translator), etc. Yet, there are differences, too, especially in the thematic focus (Hermeneutics covers both literary and non-literary translation, whereas Levý focuses solely on literary translation) as well as the method of enquiry in general: Levý (at least in The Art of Translation) did not subscribe to idealism as part of his scientific method, which he wanted to be exact and undisputable. Other discrepancies involve some of the TS concepts in Levýs works. One would hardly find the idea of a personal link between text and its recipient, which is typical for Hermeneutics, the concept of interpretation is different, as is that of subjectivity. At the same time, there are some aspects of a potential overlap between the two approaches (e.g. non-rational and subjective aspects of the literary/ translation process), which Levý reflected upon, but refused to consider in detail, since, at his time, science lacked exact methods to study the phenomena.
\end{abstract}


To sum up, Levýs work can of course be subject to 'hermeneutic reading. However, rather than a (direct) predecessor, Jiří Levý himself can be regarded as a precursor of the hermeneutic motion in Translation Studies. Nevertheless, his theory continues to be inspiring in its openness and dynamism.

Key words: Jiří Levý, Translation Studies, metatheory of Translation Studies, Hermeneutics, Prague Structuralism, Interpretation of a work of art, Subjectivism

\section{1. Úvod}

Název tohoto př́spěvku je záměrně dvojznačný. První jeho interpretace směřuje ke způsobu, jakým se čtenář může vyrovnávat s Levého teoretickými díly: pod určitým zorným úhlem, z pozice určité metody, zde tedy metody hermeneutické. $V$ tomto smyslu je možné titul přeformulovat na „Interpretace děl J. Levého z pohledu hermeneutického př́stupu v translatologii“. Druhé „,̌̌tení“ pak znamená způsob osobní recepce, kterou můžeme nazvat hermeneutickou, tedy to, jak čtenáŕ vstupuje do interakce/dialogu s recipovaným dílem. Číst „hermeneuticky“ v tomto smyslu znamená nechat se vést zásadou otevřenosti vůči recipovanému textu/dílu a vstoupit s ním do dialogu s vědomím své současné pozice, akumulovaného očekávání a také s očekáváním podnětného vztahu vzájemnosti.

Navážu-li na druhou interpretaci názvu př́spěvku, rád bych pojednání zahájil osobní vzpomínkou. Tímto článkem se vracím ke studentským létům, kdy jsem si kladl otázku po vztahu Levého díla a hermeneutiky. Tato otázka vyvstala při př́pravě na zkoušku z teorie překladu u dr. Ivany Vízdalové ${ }^{1}$, erudované translatoložky a literární vědkyně, která v Ústavu translatologie Filozofické fakulty Univerzity Karlovy položila základy pro výuku teorie překladu se zaměřením na německy mluvící země. Při čtení prací německé neohermeneutické školy v oblasti teorie překladu jsem se podivoval nad podobností některých stanovisek $\mathrm{s}$ těmi, která jsem znal $\mathrm{z}$ děl Jiřího Levého. S časovým odstupem jsem uvedenou souvislost prozkoumal bliže a zde tedy předkládám výsledky svého průzkumu.

V odborné literatuře je Levý primárně spojován s pražským strukturalismem, přičemž jeho teorie je považována za výrazně interdisciplinární. Zdá se však, že mé výše uvedené intuitivní přiřazení (podobnost Levého konceptů s hermeneutikou) odpovídá širši zkušenosti, protože reflexe možných vazeb mezi Levým a neohermeneutickým přístupem v translatologii (dále též zjednodušeně „hermeneutika“) se v odborném diskurzu objevují. Ostatně to, že mezi oběma př́istupy existuje určitá př́ibuznost, je nesporné. Zbývá však na základě bližšího prozkoumání ověřit, jak rozsáhlý takový názorový nebo metodologický průnik je.

Stěžejní výzkumná otázka přítomného pojednání je následující: Do jaké míry lze Levého považovat za předchůdce hermeneutického směru v translatologii? Metodologicky se článek opírá o výzkum primární a sekundární literatury a uplatňuje deduktivní metody zpracování jeho výstupu. $V$ první části bude pojednáno o východiscích studie, ve druhé se nastíní vztah mezi (pražským) strukturalismem a hermeneutikou obecně, ve třetí

1 Spolu s prof. Jiřím Veselým, někdejším vedoucím oddělení, to byla právě I. Vízdalová, kdo vtiskl zásadní podobu německému oddělení pražské translatologie, a tento přínos a inspirace nesou své ovoce dodnes. 
pak se na konkrétních pojmech a jejich obsazích představí míra průniku mezi přístupy J. Levého a hermeneutiky. V závěru pak budou shrnuta zjištění a budou nastíněny možné cesty dalšího výzkumu.

\section{1 Úvodní pojednání a definice}

Levý je dnes u nás a namnoze i mezinárodně uznáván jako „teoretik překladu, který ukázal nové směry v oboru“ (Schultze 2015, překlad T. S.) či jako teoretik, jehož mnohé myšlenky byly v posledních desetiletích potvrzeny ve své platnosti (srov. Mary Snell-Hornby 2006). ${ }^{2}$ Levý je u nás - zajisté správně - chápán jako teoretik překladu vycházející z pražského strukturalismu. Pražský strukturalismus byl natolik otevřeným vztahovým systémem, že katalyzoval interdisciplinaritu. Některé pojmy a př́istupy, které se později běžně přičítaly poststrukturalismu (fenomenologický př́istup, subjektivita), nacházíme již u Levého předchůdců (např. Mathesius). Některé pojmy, jež mohou Levého předurčovat k zařazení do hermeneutického směru, se pak při podrobnějším pohledu ukazují jako rozpracování již stávajících východisek strukturalismu.

Kde se tedy vzala premisa, že Levý se názorově prolíná s pozdější hermeneutikou? Podobný dojem, jako jsem zmínil v úvodu, Levého práce zanechaly také na J. Špirka (srov. 2016: 90) a údajně nemálo představitelů německé translatologie tradičně pojímalo a pojímá Levého jako příslušníka hermeneutického směru. ${ }^{3}$ Nejnověji pak do prrímé souvislosti uvádí Levého s hermeneutikou M. Suchomel. ${ }^{4}$

Hermeneutiku, přesněji neohermeneutický směr v teorii překladu / translatologii, zde přiznaně reduktivně (pars pro toto) chápeme jako zejména v (západním) Německu koncem 70. a v 80. letech 20. století etablovaný směr reagující převážně na pozitivismus Lipské školy. Hlavními představiteli hermeneutiky v teorii překladu jsou zde tedy Fritz Paepcke a Radegundis Stolzeová. Strukturalismem zde rozumíme primárně strukturalismus pražský.

\section{Mezioborové vazby translatologie, teorie překladu, strukturalismu, fenomenologie, hermeneutiky a recepční školy}

O tom, že strukturalismus a hermeneutika nejsou v protikladu, že však každá disciplína postupuje jinými metodami, hovoří hermeneutik Paul Ricœur ${ }^{5}$. Ostatně epistemologie

2 Tato recepce není s ohledem na izolovanost tehdejšího komunistického Československa vưči Západu samožrejmá. Různá nedorozumění, ke kterým při recepci českého strukturalismu a Levého díla dochází a jež nejsou „znám[a] či přiznán[a]“, vypočítává Z. Jettmarová (2016: 99) a uvádí je na pravou míru. Ostatně mezinárodní uznání skutečně převratného Levého díla je v nemalé míře výsledkem soustavné péče o Levého odkaz ze strany translatoložek Zuzany Jettmarové a Jany Králové. K dobovému kontextu a recepci díla J. Levého srov. např. také Králová, Svoboda 2016.

3 Takto se vyjádřila přední hermeneutička teorie překladu Radegundis Stolzeová na konferenci THK v Kolíně nad Rýnem v červnu 2016. Srov. též Nord 1995: 39.

4 Srov. Suchomel 2017.

5 Srov. Ricœur 1969: 33. Strukturalismus tak poskytuje objektivitu a hermeneutika existencialitu. I. Wutsdorff (2006) např. hovoří o hermeneutice a strukturalismu jako o dvou hlavních liniích literární vědy. 
pražského strukturalismu předjímá Ricœurovu „vědu o individuu“ (srov. Doležel 2000). Obecný poznatek, že mezi strukturalistickým konceptem a hermeneutikou nemusí být zásadní rozpor, ilustruje pojem jednoho z nejvýznamnějších představitelů filozoficky a jazykově orientované hermeneutiky 20. století Hanse Georga Gadamera „strukturovaná jednota“ (Gadamer 1977) ve smyslu jednotnosti (literárnosti) textu.

Čeští strukturalisté překračovali tradičně vnímaná omezení strukturalismu mimo jiné tím, že se zaměřovali na fenomenologii a recepci. ${ }^{6}$ Recepční hledisko později rozpracovala hermeneutice blízká recepční škola, jež vedle určitých sociologických rysů (sledovat vývoj skutečné recepce, nezabývat se domnělým recipientem) zavádí právě i rysy hermeneutické: Její významný představitel H. R. Jauß hovoří o „předporozumění z hlediska žánrü“, popřípadě o „horizontu porozuměni“'.7 J. Pechar pak dokonce uvádí, že v českém strukturalismu je to Mukařovského pojem sémantického gesta, které „V sobě skrývá poukaz k problematice hermeneutické“" 8

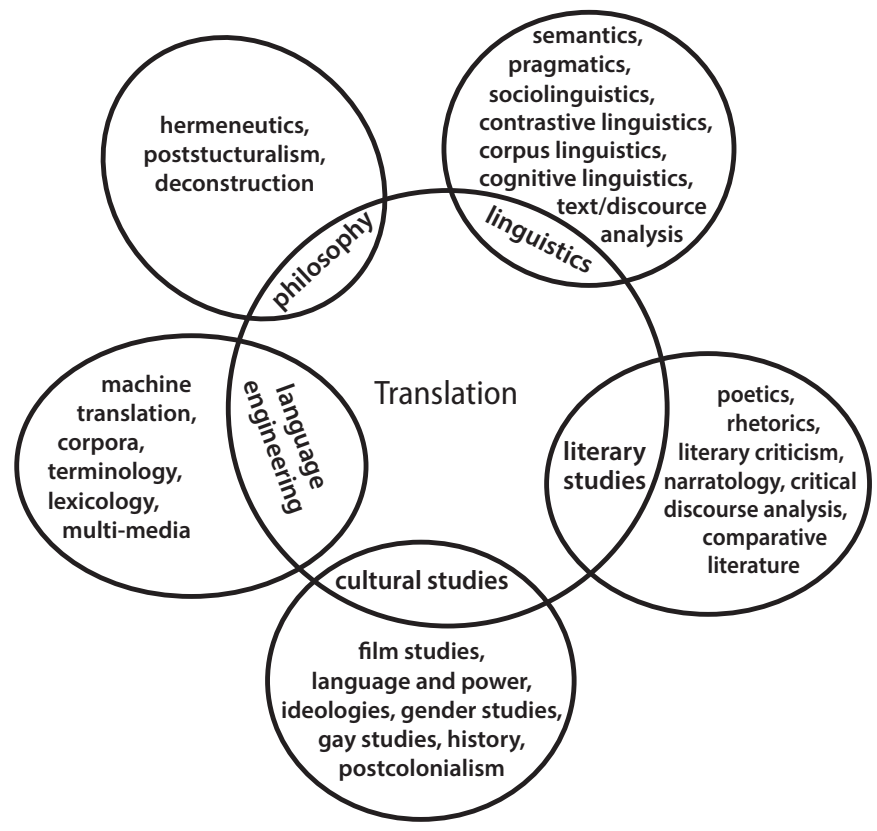

Obr. 1: Hermeneutika jako obor prolnutý s interdisciplínou translatologie prostřednictvím rozhraní oboru filozofie; in Hatim a Munday (2004: 8), viz pojednání níže

6 Srov. Králová/Jettmarová 2008: 10. K vazbě strukturalismus-fenomenologie-hermeneutika uvádí Z. Jettmarová: Do kontextu pražského strukturalismu bylo „zapojeno i fenomenologické hledisko, které se však od př́buzné hermeneutiky a tvarové psychologie lišilo mj. tím, že vedle vztahu část-celek zvažovalo vnitřní strukturu jako sít vztahů.“ (2016: 102) Fenomenologie pak se od hermeneutiky lišila i „důrazem na [...] propojenost s poznávacími dispozicemi vnímatele“ (tamt.).

7 Link 1980: 45. Př́nos pražského strukturalisty Mukařovského pro vývody recepční školy byl uznán (srov. Link 1980: 46). O vlivu Mukařovského, F. Vodičky, H.-G. Gadamera, ale také K. Kosíka na H. R. Jauße hovoří J. Hroch (2006). Dále připomíná K. Chvatíka, u nějž došlo „[k] další inspirativní recepci hermeneutického myšlení v českém strukturalismu" (s. 74).

8 Pechar 2003, bez paginace. 
V translatologii pak zdánlivý rozpor mezi ,vědeckým` strukturalismem a ,spekulativní hermeneutikou smiřuje svým integrativním př́istupem Mary Snell-Hornbyová. To pak, že hermeneutický př́stup je považován za součást translatologie, dosvědčují standardní kompendia a encyklopedie translatologie; Hatim a Munday představují hermeneutiku („,hermeneutics“) graficky jako obor vstupující do „interdisciplíny“ translatologie (zde zobrazeno jako „Translation“), prostřednictvím filozofického průniku („philosophy“) - viz obr. 1 .

Zájem o hermeneutický př́istup v translatologii v nedávné době ožil, o čemž svědčí konference, které se programově hlásí k teorii překladu / translatologii. ${ }^{9}$

\section{Př́buzná témata a pojmy u Levého a hermeneutiky}

V tomto oddílu, který představuje stěžejní materiálovou část článku, pojednáme o některých prvcích metodologie a pojmech, které naznačují průnik obsahů díla J. Levého a hermeneutiky, popř́ípadě poukazují na eventuální nespojitost těchto obsahů. Oddíl je rozčleněný na část věnovanou (meta)teorii a metodologii a na část věnovanou konkrétním pojmům literární teorie a teorie překladu (a dalších souvisejících disciplín) s úseky týkajícími se pojmů text/dílo obecně, překlad jako proces, čtenáŕ / recepce textu, překlad jako produkt a překladatel.

\subsection{Obor/oblast zkoumání, metodologie}

\section{Oblast zkoumání, vědecká metoda}

Pokud jde o tematickou oblast Levého zájmu, je jasné, že Levý se soustředil na literárněvědnou teorii překladu, přičemž tuto skutečnost připisuje jakési preferenci geopolitické: „Na Západě je v popředí především obecná lingvistická teorie překladu. [...] V našich zemích se naproti tomu teoretická literatura ponejvíce specializuje na umělecký překlad a jeho kritiku a vidí specifickou problematiku s větší jasností." ([1963]/1998: 19) Jeho metoda práce je obecně orientovaná na exaktní př́stup ${ }^{10}$ - podobný metodě př́rodních věd, tedy ve smyslu vyloučení subjektu zkoumatele (nikoli ve smyslu nezájmu o subjekt či individualitu) -, což se podstatně rozchází s hermeneutickou metodou. Zároveň však není scientistická ${ }^{11}$ (srov. např. Levého umírněnou a $\mathrm{k}$ fenoménu zapojení člověka přihlížející aplikaci teorie informace na literární proces - Levý 1971). Levý odmítal jednostranný idealismus v teorii překladu a vítal její „uzemněni“ (výraz J. Levého) metodami lingvistickými (srov. 1998: 39). ${ }^{12}$ Zde je patrný rozdíl vůči hermeneutice, která naopak vyhledává idealistický ,vzlet“.

9 Srov. činnost výzkumného centra v Kolíně nad Rýnem či v roce 2016 tomuto tématu věnovanou konferenci v Č́ně.

10 Chvatík (2001) Levého explicitně zmiňuje jako představitele „exaktního“ křídla pražské školy šedesátých let 20. stol. Danou okolnost dále dobře dokumentuje i fakt, že Levý v této době založil Skupinu pro exaktní metody a mezioborové vztahy.

11 Takto se může jevit metoda některých slovenských teoretiků překladu, popřípadě představitelů slovenského strukturalismu (srov. Jettmarová 2008: 23).

12 Levého, zdá se, poněkud dráždilo „schematizujicí pojetí, jež nachází u některých teoretiků, kteří hovoří např̀ o metamorfózách, archetypu, používají obrazný jazyk (př́měr k vazbě mezi texty jako ke vztahům v rodině) apod. Takové pojetí nazývá (nikoli v obdivném smyslu) „fantastickym“ a poukazuje také na to, že je problematické „praktické využitî“ takového pojetí (1998: 38). 
Jak velmi př́ípadně připomíná M. Suchomel (2017: 5), Levého př́stup je zároveň charakterizován vědeckou pokorou, když Levý (na více místech) uznává, že jím předložené teorie a modely jsou namnoze parciální, dočasné, některé hypotetické. ${ }^{13}$

Levého primární ${ }^{14}$ zaměření na umělecké texty paradoxně zmenšuje průnik jeho teorie s pozdějším neohermeneutickým prrístupem $v$ translatologii, jenž se totiž nesoustředuje jen na umělecké texty, ale i na překlad neliterární.

\section{Provázanost teorie a praxe}

Obecně se má za to ${ }^{15}$, že se Levý svými texty orientoval mimo jiné na praktikující překladatele, a jistě to tak i bylo. ${ }^{16}$ Teorii překladu totiž vnímal nejen jako zdroj pro praxi pedagogickou ${ }^{17}$, ale i mimo ni celkově požadoval "praktické využití 'teoretických pojetí a metodologických př́stupů.

V hermeneutice nacházíme podobný př́stup: Fritz Paepcke jako představitel neohermeneutického směru v translatologii uvedl, že „[j]e zapotřebí, aby teorie překladu [...] otevírala cestu překládání a aby je empiricky ověřovala“ (Paepcke [1979]/1986: 102, překlad T. S.). I Radegundis Stolzeová spatřuje úlohu teorie velmi podobně jako Levý18, v propojení teorie a praxe však jde místy ještě dále, když explicitně uvádí, že svou publikací usilovala o to dát překladatelům do rukou nástroj, který by mohli prakticky uplatnit při práci. ${ }^{19}$ Nápadná shoda u obou př́stupů (Levého a hermeneutiky) pak dále spočívá $\mathrm{v}$ tom, že v obou př́padech pracují s rozsáhlým př́íkladovým materiálem.

\section{Téma hry}

Nápadný tematický průnik mezi Levým a hermeneutikou nacházíme v tom, že v obou prrípadech je rozpracováno téma hry, byt vyznění tohoto tematického aspektu je výrazně odlišné. Hermeneutika - v opozici k názoru, že každá lidská činnost je určována nějakým účelem - používá příměr hry ${ }^{20}$ mimo jiné k poukazu na „nesmyslnost“ hry jako lidské činnosti, tedy na absenci účelu takovéto jednání: Jaký je „účel“ např. dětské hry či

13 Např́klad: „[Naše a]plikace komunikačního modelu na literární proces má některá zásadní omezení a nebezpečí, z nichž zcela základní význam má ta skutečnost, že vcelku není schopen vystihnout literární dílo jako historicky konkrétní a historicky podmíněný fakt. [... Náš model je] částečný model, který nevystihuje podstatu literatury." (1971: 69n).

${ }^{14}$ Levý se ve svých pracích nezabýval výhradně literárními texty, nalezneme u něj pasáže dotýkající se „odborného překladu“ (Levý 1998), „neliterárního textu“ (Levý 1971) apod., jsou to ale zmínky spíše doplňkového charakteru.

15 Srov. Hausenblasův úvod in Levý 1998, podobně též viz Hrabákův doslov in Levý 1971: Levý „se zaměřoval na potřeby spisovatelské praxe, zejména překladatelské“.

16 I když v roce 1963 uvádí, že „není možno, a ani záhodno, psát návod k překládání“. Zároveň však dodává, že cílem dané publikace (Umění překladu) je „osvětlit problematické stránky překladatelské práce. Jde o to, ukázat problémy a naučit o nich překladatele teoreticky uvažovat.“ (Levý 1998: 42n).

17 Srov. stat Bude teorie překladu užitečná překladateli̊m? z r. 1965 (in Levý 1971; zde pak zejm. s. 47).

18 „Vědecké zkoumání [...] je předpokladem a součástí hermeneuticky orientované teorie překladu. Jako didaktický cíl z toho přitom vyplývá [...] zlepšovat povědomí [Sensibilisierung] překladatelů, pokud jde o rozličné aspekty, jež se při překladu uplatňují..." (Stolze 1992: 265, př̌eklad T. S.). Nebo: Teorie překladu je „reflektovaná praxe“ překládání (tamt., s. 14).

19 Srov. Stolze 1992: 265.

20 Výběrově: „Překladatelská činnost žije z radosti ze hry“ (Paepcke 1986: XV), „Cílem je pokusit se o nový př́stup tematizací vztahu mezi pravidly a hrou“ (Paepcke 1981, in Paepcke 1986: 123, překlad T. S.). 
kreativního tvoření? ${ }^{21}$ Pro hermeneutiku tedy může být překladatelská činnost (zejména u literárních textů) „bezcílná“, popřípadě může mít smysl sama v sobě. Levý však ve své teorii uplatnil matematickou teorii her, jejímž cílem bylo naopak „algoritmizovat“ rozhodovací proces, uvést jej na pevnou půdu racionálna. ${ }^{22}$

\section{Téma rozhodovacího procesu}

Pokud pak jde právě o koncept rozhodovacího procesu, je to samozřejmě pro Levého jedno ze stěžejních témat (srov. Levý 1971). Na velké ploše líčí podrobnosti své teorie a rozpracovává tento námět jak pro aspekt geneze, tak pro aspekt recepce literárního díla. Vedle popisu principů a souvislostí podobných matematické teorii her (volba z více možností za určitých podmínek) si je J. Levý vědom toho, že volby aktérů hry mohou být i neracionální: Pravidla pro určitou volbu na straně účastníka hry totiž připouštějí vedle přistupu intencionálního také přístup pravděpodobnostní, podřízený náhodě. Srov. vlastní stanovisko Levého, které je (ve srovnání s publikací Umění překladu) nezvykle otevřené principu intuice. Na místě, kde popisuje výklad geneze Havrana z pera E. A. Poea, uvádí: „Nezáleží zde na tom, zda jednotlivá rozhodnutí byla skutečně činěna racionální úvahou[...] Podstatné je, že Poe popsal sérii rozhodnutí, jež at̉ už racionálně nebo intuitivně musel učinit“. A dále: „mnohé z těchto nutností jsou náhodné, [...] jsou podmíněny [mimo jiné...] individuální zálibou“.23 Následně pak Levý uvádí tento svůj metodologický „krok stranou“ na pravou míru, když snahu o postižení příčin rozhodovacího procesu odkazuje do sféry „literární psychologie“: „[P]řričiny [rozhodnutí] jsou zpravidla v básníkově subjektu“ (1971: 94). A v logice svého exaktního přístupu pak nemůže Poea nepokárat za „zamlčený soubor instrukcí ŕídících výběr mezi členy paradigmat“, totiž zamlčenou estetickou normu. Celkově však lze říci, že jestliže Levý ve svém výkladu uvádí, komentuje či kritizuje některé neexaktní pojmy, neznamená to, že by je zpochybňoval jako takové, ale eventuálně kritizuje jejich uplatnění metodologické, zejména ve vědeckém diskurzu.

Jinými slovy: Levý o neracionálních a subjektivních aspektech literárního (a předpokládejme: i překladového) procesu ví, ale kvůli metodologickým ohledům o nich nehodlá blíže pojednávat. Konkrétní zdůvodnění - opět z oblasti problematiky rozhodovacího procesu - zní: „Všechna jiná kauzální vysvětlení relegují příčiny rozhodování do oblasti mimoliterární, př́írodovědné, již literárněvědnými metodami nemůžeme adekvátně zkoumat." (1971: 94) Argument se zde ale zdá být poněkud vyhýbavý až vágní, vždyt” Levý při jiných př́ležitostech neváhal používat metody, jež zdaleka nebyly běžné v literárněvědném zkoumání (např. do studia verše zapojil úvahy spojené s kybernetikou), ostatně totéž platí pro oblast teorie překladu, kde např. navrhnul sociologické postupy tam, kde do té doby navrženy nebyly (například zohlednění problematiky výběru díla $\mathrm{k}$ překladu).

21 Dítě si jistě nehraje, aby se utilitárně přiblížilo naplnění určitého cíle. Podobně autor či kreativní překladatel svou tvůrčí činností vůbec nemusejí sledovat konkrétní cíl - srovnejme zde Mukařovského pojem samoúčelnosti estetična; marxistickou terminologii uspokojování estetických potřeb snad nemusíme vnášet do tohoto diskurzu, ostatně považovat život člověka za pouhý řetězec uspokojování potřeb by bylo navýsost reduktivní.

22 Tomu pak odpovídá Levého kritika J. M. Lotmana, kterému vyčítá, že při aplikaci teorie her v literární vědě se ve výkladu o vzniku estetické libosti „přenáší do nekontrolovatelné oblasti psychologické hypotézy“ (1971: 141).

23 První citát: Levý 1971: 91, druhý citát tamt. s. 93, v obou př́padech kurziva T. S. 
Uvedli jsme pohled Levého na rozhodovací proces, zbývá doplnit pohled hermeneutiky. Konkrétně F. Paepcke (1971) formuluje následující definici: „Překládání je na jednání orientovaný rozhodovací proces "24, činí tak tedy cca čtyři roky poté, co v Haagu vyšel anglicky - a byl široce recipován - Levého článek Translation as a decision process (1967). To, zda se jedná o prŕmou (a nepřiznanou) recepci Levého ze strany F. Paepckeho, nelze $\mathrm{s}$ jistotou tvrdit z důvodu absence bližších indicií či podrobnějšího výzkumu.

\section{Jazyk Levého díla, vývojový aspekt uplatněných pojmů}

Hermeneutický přístup je známý tím, že o pojednávaných skutečnostech vypovídá za použití abstraktních pojmů, častá jsou přirovnání, metafory, filozofický jazyk. Jazyk Levého studií je naproti tomu velmi racionální a stř́ímý ${ }^{25}$, na druhou stranu není zcela prost obrazných vyjádření:

„Pozorujeme-li překlad [...] z ptačí perspektivy celistvého působení tohoto zprostředkujícího komunikačního činitele na celou rozlohu soudobé kultury, vystupuje do popředí [...] skutečnost, že určité množství vyhraněných a vynikajících osobností se v jistém ohledu drobí ve větší množství menších a matnějš́ch osobností překladatelů." (1971: 157, kurziva T. S.)

Podobně Levý tvůrčí proces překladu v užším slova smyslu metonymicky označuje jako „cestu“ a vnímání/interpretaci díla jako pronikání „za text":

„[P] řekladatel tvůrčí $[\ldots]$ na cestě mezi originálem a překladem [...] proniká za text $\mathrm{k}$ postavám, situacím a ideám, kdežto překladatel netvưrčí mechanicky vnímá jen text a překládá jen slova.“ (1998: 56, kurziva T. S.)

Zdánlivá př́stupnost Levého textů (zejména to platí o Umění prekladu) může evokovat představu esejisticky pojatých pojednání. Při druhém pohledu (a mnoha dalších pohledech) však vysvítá, že se jedná o náročné a sofistikované vědecké pojednání.

Práce Levého navíc zřejmě vykazují určitý vývojový aspekt v pojetí některých podstatných pojmů. Např. u pojmu intuice zjištujeme, že jestliže ještě v Umění prekekladu (r. 1963) Levý (metodologickou) intuitivnost druhých přirovnává k laickosti (1998: 34), v Genezi a recepci literárního díla (vyšlo převážně v r. 1966) sám o svém postupu uvádí: „Naše dosavadní úvahy o překládání se intuitivně opírají o empirický poznatek, že překládání je rozhodovací proces [...]; dosud jsme se jej ale neodvážili naplno vyslovit..." (1971: 72). Nejde ani tak o změnu denotativního obsahu tohoto pojmu, spíše o proměnu kontextu, ladění, o reflektivní pokoru, hodnoticí obsazení tohoto pojmu.

24 Paepcke 1971: 115, překlad T. S., kurziva původní.

25 Což nepochybně souvisí s metodologií Levého, dobovým územ a též s tradicí pražského strukturalismu: „Postmoderní př́stup ke konceptům, jenž si libuje v metaforičnosti, je pražskému strukturalismu [...] cizí" (Jettmarová 2008: 128, překlad T. S.). 


\subsection{Konkrétní pojmy literární teorie, teorie překladu (a dalších souvisejících disciplín)}

\subsubsection{Text/dílo obecně}

Jedním z pilířu hermeneutického pojetí textu je tzv. nadsumativita, tedy okolnost, že celek textu je více než součet jeho částí. ${ }^{26} Z$ de je nepochybně patrný potenciálně rozsáhlý průnik mezi pojetím díla u pražského strukturalismu (díky jeho pojetí díla jako dynamické struktury) a u hermeneutiky. Levý sám o nadsumativitě nehovoří, ale souhlasně cituje př́buzný názor polského teoretika překladu Z. Klemensiewicze, který operuje se systémovým pojetím textu ve smyslu organického celku. ${ }^{27}$ Pokud jde o uspořádání díla, je to pro Levého na jedné straně „postupně se uskutečňující stavba“ 28 (příměr, který by obstál v každé učebnici hermeneutiky), na druhou stranu se však zamýšlí nad „exaktním [...] vyjádření $[\mathrm{m}]$ uspořádanosti literárního díla", včetně eventuálně vyjádření matematického. ${ }^{29}$

\subsubsection{Překlad jako proces}

V souvislosti se šířeji pojatým procesem, zahrnujícím autora originálu, překladatele

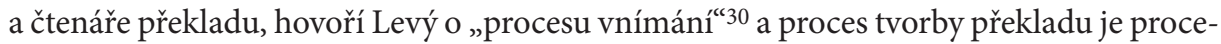
sem uméleckým. ${ }^{31} \mathrm{~S}$ tím koresponduje názor hermeneutiky, který obdobně spojuje procesualitu, vnímání a pojem uměleckosti: „Individuálně laděné rozumění je pak, dovedeno do extrému, ,uměním rozumějícího subjektu“.32

\subsection{3 Čtenář, recepce textu, výklad, pochopení, porozumění textu, dialog s texty}

Levému je text „objektivním materiálem“, který je recipován v podobě čtenářské konkretizace..$^{33} \mathrm{Z}$ toho je patrné, že $\mathrm{v}$ Levého studiích se nepředpokládá vytvoření vzájemnosti mezi textem/dílem a jeho recipientem, jež je však tak typická pro hermeneutický přistup. ${ }^{34}$ Lze však přesto předpokládat, že se Levý jinak otázkou vnitřní spřízněnosti recipienta s dílem zabýval, ostatně v Českých teoriích překladu v oddílu Literární skupiny

26 Srov. např. Paepcke 1979, in Paepcke 1986: 103, u Levého pak např. celý oddíl nazvaný „Celek a část“ (in Levý 1998), kde se mj. pracuje s funkčním hlediskem a dialektikou jedinečného a obecného.

27 „Originál je třeba chápat jako systém, a nikoli jako souhrn elementů, jako organický celek, a nikoli jako mechanické seskupení elementů“ (Klemensiewicz, in Levý 1998: 63).

28 Levý 1971: 47.

29 Tamtéž, kurziva T. S.

30 Srov. 1998: 49. K poststrukturalistickým lingvistickým tendencím, mezi něž patří např. i souvislost s kognitivní lingvistikou, viz např. Tabakowska 2015.

31 Ostatně pro Levého, jak známo, je překladatelství „typem uměni“ (viz přímo takto nadepsaný pododdíl, in 1998: 84), notoricky známé je jeho stanovisko, že „[p]řeklad jako dílo je umělecká reprodukce, překlad jako proces je původní tvoření (1998: 85), a dále též rozlišuje jako jednu ze dvou stěžejních norem, jež do tohoto procesu vstupují, normu uměleckosti.

32 Link 1980: 115, s odkazem na W. Windelbanda.

33 Viz Levý 1998: 49. U pojmu konkretizace připomeňme jeho původce, fenomenologa R. Ingardena, u nějž však znamená spíše to, jak čtenář (svou představivostí, ve svém vědomí) vyplňuje „,nedokreslená “ místa v textu. K recepci, či spíše realizaci díla, srov. postř̌eh M. Suchomela: „Heidegger a Levý by se pravděpodobně shodli, byt velmi specifickým způsobem, že dílo je dáno jako něco, co je skutečné jen ve své realizaci“ (2017: 3, překlad T. S.). K prrekladatelskému procesu u Jiř́ho Levého viz též T. Svoboda 2004.

34 Srov. F. Paepcke: „Jakmile se při překládání podaří překonat situaci opakujících se nezdarů při překládání, vytvoři se mezi textem a překladatelem pospolitost, vzájemnost, přičemž si každý text uchovává svou individualitu..." (Paepcke 1985, in: Paepcke 1986: 159, překlad T. S.). 
z konce 19. století zmiňuje „tezi v překladatelství, podle níž „překladatel si má osvojit původní psychické stavy, za nichž vznikalo dílo. [S autorem pak] musí být duševně spřízněn“ (Levý [1957]/1996: 195). Hned poté zmiňuje téma překladatelské kongeniálnosti. Uvedenou „tezi“ sice řadí mezi subjektivistické, ve svém historickém výkladu ji však dále ponechává bez dalších komentářù, a bezprostřední kontext nenaznačuje, že by se jednalo o referenci nesouhlasnou.

\section{Vnímání, chápání, pochopení, porozumění, interpretace}

K objektivní ideji díla lze podle Levého přistupovat vědeckou nebo uměleckou interpretací35, která však nesmí do díla vkládat „výklady nesourodé, odporující objektivní ideji“ (1998: 64). Podobně jako subjektivitu Levý i pojem interpretace (výkladu) spojil spíše s negativními konotacemi. ${ }^{36} \mathrm{Z}$ hlediska historické spravedlnosti je zde však třeba doplnit, že Levý byl (už v roce 1955) veřejně kritizován za svůj pojem čtenářské konkretizace jako za pojetí př́lišs subjektivistické. Zdá se tedy, že pro svou pozdější knihu (Umění prekladu) byl do jisté míry nucen svá stanoviska takovým invektivám podřídit a pojem subjektivity interpretace/konkretizace snad proto obsadil převážně negativně. Ještě při dané př́ležitosti (jednalo se o konferenci) však reagoval slovy, že skutečně subjektivní složku není možno z umělecké tvorby vyloučit. ${ }^{37}$

Interpretaci, jak známo, Levý popsal též jako jednu z fází překladatelského procesu v užším slova smyslu (viz níže), a dokonce tuto fázi dále rozčlenil na další tři podfáze. ${ }^{38}$ A právě zde, konkrétně u fáze volby interpretačního stanoviska, se, byt’ velmi okrajově, u Levého objevuje na straně překladatele volní aspekt, a tedy určité uvolnění překladatelovy svázanosti objektivní ideou díla: Překladatel totiž „ví, co chce sdělit čtenáři“ (1998: 61), může si zvolit, že vyzdvihne „všelidskou podstatu a všelidský typ“ sdělení textu (řečeno s Mukařovským: antropologickou konstantu). Na druhou stranu Levý vcelku bez obalu připojuje, že překladatel je poprrípadě korigován dobovou ideologií (srov. pojem „ideologické stanovisko“ na s. 104 - můžeme jen spekulovat, zda zde má na mysli cenzuru) či „kulturními potřebami doby“" (s. 102).

U Levého tak postrádáme otevřenost významového horizontu vůči jiným než intersubjektivním, kolektivním interpretačním počinům, jež je naopak příznačná pro hermeneutický př́stup. ${ }^{39}$

35 Srov. Levý 1998: 49. Ostatně „každý překlad je více či méně jasná interpretace“ (1998: 61).

36 Viz např.: „Překladatel má $\mathrm{k}$ textu poměr interpreta, proto text nejen překládá, ale také vykládá, tj. zlogičtłuje, dokresluje, intelektualizuje. Tím jej často zbavuje umělecky účinného napětí mezi myšlenkou a jejím vyjádřením.“ (1998: 145) Levý též používá např. sloveso „vinterpretovat" ve smyslu vnést do díla vlastní, nemístné myšlenky. Okolnost, že strukturalisté se spíše vyhýbali pojmu interpretace a namísto toho dávali přednost pojmu konkretizace, rozebírá J. Schneider: „pojem interpretace zjevně nepatří do strukturalistického žargonu“ (2006: 93).

37 Viz zpráva z I. celostátní konference o uměleckém překladu, in: Literární noviny č. 50/1955, s. 8 (dostupné přes digitální archiv ÚČL AV ČR). Zmíněná invektiva p. Mikuly zní: „Čtenář, konsument literatury a v konečném důsledku naše národní kultura není zvědavá na subjektivní čtenářskou konkretisaci nějakého překladatele, nýbrž na dílo [původního] autora [...]“. (Za upozornění na tento zdroj děkuji Z. Jettmarové.)

38 (i) Hledání objektivní ideje díla, (ii) interpretační stanovisko překladatele, (iii) interpretace objektivních hodnot díla.

39 K pojmu otevřenosti významového horizontu srov. např. Stierle 1975/2001: 199. Na druhou stranu však i Stolzeová, cca 30 let po Levém, pracuje s termínem intersubjektivity (pojmu věnuje celý oddíl), srov. 1992: 31. 
Velmi výraznou styčnou plochu lze naopak najít mezi pojetím hermeneutického kruhu a Levého výkladem o vnímání na straně čtenáře. ${ }^{40}$ Levý proces vnímání líćí takto: „Vnímá-li tedy čtenář $\mathrm{v}$ daném okamžiku [...] jazykový segment [...], pak se v něm současně naplňují nebo zklamávají očekávání vytvořená během předchozí četby." (Levý 1971: 46). A dále: „[D]ílo není jednou provždy daný tvar, ale postupně se uskutečňující stavba, takže např̀. tentýž motiv se na konci díla jeví v jiném významovém kontextu než na počátku“" (Levý 1971: 47).

Následující diagram zmíněný proces názorně ilustruje:

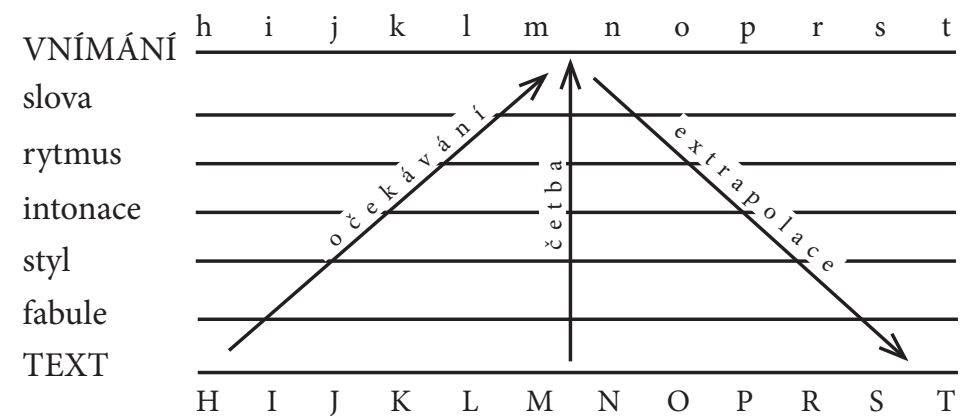

Obr. 2: Levého schéma vyjadřující proces vnímání na straně čtenáře (in Levý 1971: 46)

Horizontální osy VNÍMÁNÍ a TEXTU je třeba chápat jako kontinuum, na němž se postupně (chronologicky) uskutečňuje čtenářova percepce. Šipky „očekáváni“ a „extrapolace“ mají v diagramu rovněž svůj význam „vývojový" ${ }^{41}, \mathrm{v}$ tom smyslu, že ukazují nárůst očekávání před aktem vnímání, a to s odlišnou intenzitou na různých rovinách (či „složkách díla“: slova - rytmus - intonace - styl...), popřípadě ukazují dopředné odeznívání extrapolace („specifický dosah“ či „,intenzitu prediktability“), jež je rovněž rozličné v závislosti na konkrétních složkách díla. S výše uvedeným souvisí i další styčná plocha mezi hermeneutikou a Levého pojetím vnímání, a to právě zmíněný pojem „očekávání vytvořená během předchozí četby“ (popřípadě „předpoklad pro extrapolaci do budoucnosti“; srov. Levý 1971: 46), který jednoznačně koreluje s hermeneutickým pojmem „horizontu očekávání“42

Je nasnadě, že téma porozumění či výkladu textu je prvořadou doménou hermeneutického př́stupu v teorii překladu: „Kdo překládá, musí nejprve porozumět textu,“

40 Domníváme se, že tomuto př́měru nebrání ani fakt, že vnímání/porozumění u Levého je „inkrementální" (srov. Jettmarová 2014: 175) a že překladatelský proces jak z hlediska komunikativního zapojení, tak na úrovni samotného překladatele je u Levého prezentován striktně lineárně (srov. Levý 1998 a 1971).

41 Z. Jettmarová při popisu tohoto Levého modelu hovoří o „systému učeni“ („learning system“, srov. Jettmarová 2014: 175). Na jiném místě potvrzuje, že souvislost s hermeneutickým pohledem na kognitivní proces je zde zřejmá: „Tento [Levého] model recepčního procesu anticipoval principy recepční estetiky (Kostnická škola) a také možné pokusy integrovat hermeneutiku“ (Jettmarová 2008: 27, překlad T. S.).

42 Dodejme, že k pojetí horizontu očekávání a hermeneutického kruhu má blízko i pojem pasivního idiolektu v širokém pojetí, na které odkazuje a které rozpracovává Levý (1971: 48). 
symptomaticky uvádí Paepcke. ${ }^{43} \mathrm{~K}$ tomu je zapotřebí zapojení jak racionální úvahy, tak i intuice. ${ }^{44}$ Intuice je pro hermeneutiku sondáží, „odposloucháním“ a haptickým vnímáním (hmatáním) - jakoby „poklepem a poslechem“. Levý pak s pojmem intuice pracuje minimálně.

\section{Výklad a individualita, subjektivita-objektivita}

Předně je zapotřebí odlišit individualitu od subjektivity. Rozměr individuality Levý přiznává výkladu: díla je zapotřebí - po ideové stránce - vykládat individuálně 45 . Podobně, leč poněkud více textově-imanentně formuluje Paepcke (1979, in Paepcke 1986: 103): „Každý text [disponuje] nezaměnitelnou individualitou.“ Z. Jettmarová (2016: 93) pak dodává, že Levý připisuje „významnou roli [...] osobnosti (individuu), tedy jednání člověka na úrovni individuální i kolektivní."

Pokud jde o subjektivitu ${ }^{46}$, Levý nezastává iluzi objektivity na straně jednotlivého čtenáře, pokud jde o vnímání díla. Pojmy subjektivní-objektivní (vyznění, přístup, platnost) používá dialekticky, navíc nikoli ve smyslu neměnné imanence $\mathrm{v}$ díle či čtenáři. Srov. následující výrok, který je pro pochopení této vazby stěžejní: „[V] překladu se bude někdy rozcházet subjektivní idea překladatelova a objektivní idea jeho překladu." (1998: 67) To znamená, že objektivní ideou (smyslem, platností, jádrem ${ }^{47}$ ) díla či překladu je potřeba chápat vyznění - čili to, jak je dílo/překlad vnímán(o)/pochopen(o). Levý navíc často operuje s pojmem „objektivní hodnoty díla“ (zde nepochybně navazuje na Mukařovského ${ }^{48}$ a jeho instrumentální definici hodnoty). Objektivita tedy u Levého neznamená nedotknutelnou a nepodmíněnou ${ }^{49}$ platnost, nýbrž hodnoty sdílené na rovině supra-

43 1979, in Paepcke 1986: 104. Ve stejném smyslu čteme u Levého známé stanovisko: „Překladatel je v prvé řadě čtenář.“ (1998: 48) Na druhou stranu však téměř totožnému (avšak o 12 let pozdějšímu) vyjádření F. Paepckeho, že totiž „prvořadou povinností překladatele je četba“ (1985: 160) je potřeba rozumět odlišně: Paepcke zde má na mysli četbu i neodvozených textů v mateřštině překladatele kvůli tř́bení jazyka, do nějž překladatel překládá.

44 „Optimální podoba hermeneuticky orientovaného překládání ostatně pramení z provázanosti rozumového principu a intuice.“ (Paepcke 1986: XVI, překlad T. S.) V originálu: „Im Zueinander von Ratio und Intuition entsteht letzten Endes das Optimum des hermeneutisch orientierten Übersetzens."

45, „[K]aždé dílo [si po ideové stránce] vyžaduje individuální výklad“ (Levý 1998: 38n).

46 Zde v poněkud odlišném kontextu srov. pojmy noetický subjektivismus a noetický objektivismus, viz např. Jettmarová 2014/2016: 171 či Jettmarová 2008: 31. Na tomto místě ještě připomeňme Levého úzus pojmu „vkus“ (srov. 1971: 104).

47 Srov. tyto obměny daného pojmu a příklady jejich výskytů: „objektivní smysl díla“ (1998: 61), „objektivní platnost překládaného/překladového díla“ (1998: 62, 219), „objektivní jádro“ (1998: 62), „objektivní idea díla“ (1998: 204).

48 Mukařovský považoval otázku, „je-li objektivní estetická hodnota skutečnost, nebo klamné zdání, za zásadní, srov. Mukařovský 1936/1966: 44, zde cit. dle Sedmidubský, Červenka, Vízdalová 2001. Uvědomoval si podmíněnost takové hodnoty: „při pátrání po [...] předpokladech objektivní estetické hodnoty nelze [...] uniknout z dosahu sociální povahy uměni“ (kurz. původní); zároveň pro něj bylo nesporné, že „umění vytvořené člověkem [...] nemůže tvořit hodnoty na člověku nezávislé“ (Mukařovský 1936/1966: 44; zde cit. dle Sedmidubský, Červenka, Vízdalová 2001). Velké pochybnosti o neměnnosti a ,objektivitě estetické hodnoty dává tušit tento jeho výrok: „Estetická hodnota je tedy proměnlivá ve všech svých stupních“ (s. 41). Pokud ji Mukařovský přeci jen připouští, soudí, že může existovat jen potenciálně: „nezávislá estetická hodnota inherentní materiálnímu uměleckému artefaktu, předpokládáme-li ji, má ovšem [...] ráz toliko potenciálni' (tamt. s. 52).

49 „Nepůjde nám nikterak o zachování díla ,o sobě, nýbrž jeho hodnoty pro př́jemce“ (1998: 41n, kurziva T. S.). Později pak místy od termínu „objektivní hodnota díla“ ustupuje a nahrazuje jej termínem „hlavní idea“ či „idea díla“ (1971: 116), přičemž přiznává, že tzv. definování takové hlavní ideje je značně „ošemetná věc“ (tamt.). 
individuality. ${ }^{50}$ Takto široce sdílenými hodnotami jsou pak konstituovány normy - slovy Mukařovského - jako fakt tzv. kolektivního vědomí. ${ }^{51}$ Navíc je tento pojem často spojen spíše s Levého metodou vědecké práce, jak dodává např. B. Schulze: „Čtenář Levého díla se musí mít na pozoru. Někdy výraz ,objektivní zkrátka znamená ,verifikovatelnýc““ (2015: 107, překlad T. S.).

Hermeneutika samozřejmě počítá s objektivním přístupem $\mathrm{k}$ realitě, nechce však zároveň opomíjet subjektivní rovinu. ${ }^{52}$ Rovněž Levý, jak jsme viděli, pojem subjektivity zná a pracuje s ním, je však v jeho úzu převážně obsazen pesimisticky, až negativně, je totiž líčen jako zdroj rizika: „Subjektivní chápání textu je [...] fakt, se kterým se musí počítat již proto, že je příčinou mnoha nebezpečí. "53 Vedle strukturalistického vlivu zde Levý mohl být ve svém pesimistickém úsudku ovlivněn též svou praxí pedagogickou a výzkumnou, kdy byl konfrontován s častými a patrně stále se opakujícími chybami začátečníků. V hermeneutickém přístupu takový skepticismus nenalézáme. Ta, zdá se, v tomto smyslu poskytuje vnímateli větší volnost a vkládá plnou důvěru ve svébytnost individua, protože nepožaduje, aby jeho intuice byla ověřena instancí kolektivní intersubjektivity. Nepochybný průnik mezi myšlením Levého a hermeneutikou však existuje v požadavku racionální kontroly nad nereflektovanou subjektivitou.

\subsubsection{Překlad jako produkt}

\section{Funkční ekvivalence, ekvivalence účinku}

Levý nepochybně přikládal zásadní význam funkčnímu hledisku, a to jak v teorii ${ }^{54}$, tak v praxi překladu (srov. 1998: 26). Funkcionalisticky je Levým interpretována i Mathesiova „rovnost [= ekvivalence] uměleckého účinku“ ${ }^{55}$, avšak nikoli v absolutním slova smyslu (stejné vjemy u čtenářů), ale relativně, v kontextu (polysystému), v němž je čtenář

50 Klíčové je zde toto vyjádření. „U realistického umělce i subjektivní stránka obrazu je výrazem neosobních, kolektivních činitelů, a proto nabývá v dané situaci platnosti objektivní." (1998: 46) Jettmarová (2008: 20) pak v tomto kontextu používá výraz „objektivita na supraindividuální úrovni, tedy na úrovni kolektivity a intersubjektivity“, popřípadě „intersubjektivní existence“. Hermeneutice blízká recepční škola hovoří nápadně podobně o „transsubjektivním horizontu rozuměni“ (Link: 1980: 46).

51 Srov. Mukařovský, J., 1936, zde převzato dle Levý 1971: 103n. Levý pak opustil - alespoň explicitně Mukařovského pojem kolektivního vědomí. Zároveň však používá termín „společenské vědomi“, a to ve smyslu „fondu vědomostí a způsobu myšlení“ či „obsahu vědomí dvou čtenářských okruhü“ (srov. 1998: 52, dále též na s. 122 a na dalších místech), tedy má na mysli čtenářské presupozice.

52 „Hermeneutika rozlišuje [...] mezi objekty/fakty s jejich analýzou/kognicí, a lidskou činností s její vnitřní motivací, tedy mezi objektivitou a subjektivitou, analýzou a evidencí, strategií a impulzem, racionálním přístupem a intuicí, inferencí a dojmem, důkazem a argumentací." (Stolze 2010: 142, překlad T. S.).

53 Levý 1998: 49; poprrípadě též: čtenářský subjektivismus je „jedním z hlavních úskalí překladatelovy práce“ a překladatel by jej měl co nejvíce potlačit (1998: 61).

54 Jakýsi extrémní funkcionalismus, který by až téměř předznamenával teorii skoposu, Levý, zdá se, nezamýšlel - pokud alespoň můžeme věřit české, anglické a německé verzi Umění překladu a nepřikloníme se ke znění jeho překladu do ruštiny. Verze CS/DE/EN čtou: „[V]ýchodiskem pro vypracování [...] specializovaných teorií překladu je rangové pořadí při zachování jednotlivých aspektů překládaného textu - a to závisí na struktuře [...] textu, a nikoli na cíli, jemuž má překlad sloužit“ (1998: 24, kurziva T. S.). V ruském překladu z r. 1974 je však opačná formulace (volně parafrázováno: pořadí invariantů, $\mathrm{z}$ nějž bude odvozena specializovaná teorie překladu, závisí na cíli, jemuž má překlad sloužit), srov. pozn. překladatele in Levý 2011: 8. E. Prunč pak (poněkud spekulativně) uvádí, že zdrojová česká verze, $\mathrm{z}$ níž byl pořízen překlad do němčiny, zde patrně pưvodně uváděla slučovací, a nikoli odporovací poměr (srov. Prunč 2001: 213).

55 Srov. př́mý odkaz in Levý 1998: 27. 
zasazen. Levému jde tedy o to, jak tyto vjemy „funguji“ v celém vztahovém systému, v němž se čtenář pohybuje. ${ }^{56}$ Podobně funkční přistup nacházíme i v hermeneutice, když Paepcke hovoří o „rovnosti ozvuku (rezonance)“57.

\subsubsection{Př̀ekladatel}

\section{Osobnost překladatele}

Zájem o jednotlivce v Levého díle samozřejmě nacházíme značný, zejména pokud jde o překladatele samotného; antropocentrismus hermeneutiky však u něj zastoupen není. Výrazný překryv nastává i v otázce vnímání, kterou ve své teorii rozpracoval do té doby nevídaným způsobem a předznamenává tak psycholingvistický a kognitivní 58 důraz, jenž se dnes začíná prosazovat jako jedna $z$ větví neohermeneutického přístupu v translatologii. Prostor osobnosti překladatele Levý dává zejména v souvislosti s analýzou/hodnocením překladů. Své novátorství v této oblasti si uvědomuje, když konstatuje, že v lingvisticky orientovaných pracích svých současníků takový př́ístup postrádá. ${ }^{59}$

\section{Dispozice/nadání, kreativita př́ekladatele}

Pojem kreativity překladatele je pro hermeneutiku stěžejní. I pro Levého je překlad projevem (nebo výrazem) „tvưrčí individuality překladatelovy“ (1998: 33, kurziva T. S.). Pojem kreativity pak rozvíjí dále, když rozlišuje mezi tvůrčím a „mechanickým“ překladatelem. ${ }^{60}$ Zřetelná shoda panuje mezi Levým a hermeneutikou v otázce toho, zda si lze překladatelské umění bezezbytku osvojit bez ohledu na jisté dispozice. Levý hovoří o talentu a nadání61 a např. Paepcke uvádí, že „překlad se lze naučit jen v omezené míře a vyučovat jej lze jen odvozeně“. 62

\section{Perspektivy pro návazný výzkum}

Dalšímu zkoumání by bylo vhodné podrobit genetický aspekt Levého díla, tedy to, jak se vyvíjelo pojetí jeho některých pojmů a konceptů. Náš rozbor připouští hypotézu,

56 „Nebudeme trvat na tom, že zážitek čtenáře originálu musí být totožný se zážitkem čtenáře překladu, nýbrž na identitě z hlediska funkce v celkové struktuře kulturně-historických souvislostí, do nichž jsou zapojeni oba čtenáŕi." (1998: 42, kurziva T. S.) Pro úplnost dodejme, že napřr. u Paepckeho (v roce 1971) nalézáme obsahově blízký termín „sociokulturní kontext“.

57 „Gleichwertigkeit der Resonanz...", viz Paepcke 1986: 138.

58 Vedle pojmu vnímání se jedná mimo jiné též o jeho pojmy vybavování a struktura paměti (srov. Levý 1998, 1971) nebo o překvapivý (a později módní) pojem „černé skř́iňky“ (1971: 12).

59 „Skoro všechny lingvistické práce [...] nechávají stranou účast překladatele na procesu překládání a na struktuře překládaných děl“ (Levý 1998: 32).

60 Srov. Levý 1998: 56. Pozoruhodnou okolnost v této souvislosti zmiňuje Schippelová (2016: 265), když poukazuje na to, že ve druhé polovině 20. století existovala na Východě ideologická doktrína „kreativního" překladu. Doplňme, že v německé translatologii je Levý v několika pracích zmíněn společně s hermeneuticky orientovaným R. Kloepperem, jehož dílo Die theorie der literarischen Übersetzung vyšlo v roce 1967 a výrazně zde ovlivnilo, spolu s Levého Uměním překladu (přeloženým do němčiny o dva roky později - 1969), teoretické reflexe o literárním překladu. Jako jeden ze styčných bodů mezi Kloepperem a Levým se právě uvádí otázka kreativity překladu (srov. Krysztofiak 2013: 15).

61 Pro „překladatelské uměni“ je dle Levého zapotřebí „představivost, schopnost objektivace a stylistické nadáni“" (Levý 1998: 83).

62, „...] das Übersetzen [ist] nur annäherungsweise lernbar und nur in einem abgeleiteten Sinn lehrbar“ (Paepcke 1968, in Paepcke 1986: 66). 
že Levý je poněkud odtažitější vưči spekulativním pojmům ve svém díle Umění překladu (které psal v ideologicky nepříznivějších poměrech), zatímco pozdější stati sebrané ve sborníku Bude literární věda exaktní vědou? (psané blíže ke konci 60. let 20 stol., a tedy $\mathrm{v}$ atmosféře určitého ideologického uvolnění) by mohly ukazovat větší otevřenost vưči transcendentním pojmům a hodnotám (srov. např. pojem intuice či frekvenci užití obrazných výrazových prostředků, o nichž bylo pojednáno výše; nápadný je tento aspekt i u volby Levým analyzovaných děl).

Taktéž se ukazuje jako úkol do budoucna popsat recepci Levého díla v německy mluvících zemích obecně a u zde významných škol a směrů zvláště, jako je hermeneutika, v přítomném kontextu tedy zejména u F. Paepckeho a R. Stolzeové, ale též u recepční školy - zde poukažme na termíny „sociokulturní kontext“ či „rovnost ozvuku (rezonance)“ a jejich možnou inspiraci Levým či pražským strukturalismem.

\section{Shrnutí}

Snažil jsem se v tomto článku prozkoumat otázku podobnosti či rozdílnosti, pokud jde o pojetí metody/přístupu a rozličných pojmů teorie překladu a literární teorie u J. Levého a v hermeneutice. Nyní tedy budou shrnuty výsledky tohoto srovnání.

\section{Metateorie a tematické dirazy}

$\mathrm{Z}$ hlediska metateoretického jsme si neohermeneutický př́stup zařadili jako jeden z proudů současné translatologie a pražský strukturalismus jako stále nosnou, zejména metodologickou platformu. Levý využil otevřenosti českého strukturalismu k vytvoření podobně otevřené (dílčí) teorie překladu. Zatímco např. v Polsku převládl lingvisticky orientovaný strukturalismus a literárně orientovaný př́stup nebyl považován za vědecký (srov. Boncza Bukowski, Heydel 2015), integrativní český strukturalismus umožňoval nejen smíření obou těchto tendencí, ale i výrazné interdisciplinární přesahy. Stejně tak i Levého záměr byl integrovat další vědecké obory, čímž je blízký hermeneutice.

Shodu nacházíme v tom, že Levý byl ve svých úvahách stoupencem funkčního př́istupu a podle některých teoretiků (srov. Stolze 2011) právě funkční přístup v translatologii vykazuje výraznou podobnost s některými rysy hermeneutiky, např. svou orientací na cílový text a pragmatiku sdělení.

Pokud jde o vědeckou metodu, v obou případech nacházíme tzv. přístup cik-cak, přičemž hermeneutika je snad o něco více orientovaná na uplatnění výsledků v konkrétní praxi.

Oba př́istupy pracují s rozsáhlým příkladovým materiálem. Avšak zatímco jazyk hermeneutických pojednání je často výrazně metaforický a velmi frekventovaná jsou abstrakta či filozofické pojmy, Levého jazyk je většinově exaktně střídmý. I u něho ale nacházíme nenáhodná obrazná vyjádření. Levý novátorsky věnuje ve své teorii široký prostor jednotlivci (vnímatel, překladatel), avšak antropocentrismus hermeneutického prŕstupu u něho nalézt nelze.

Rozdíl byl naopak zaznamenán v oblasti tematického zaměření vědeckého přístupu (hermeneutika se oproti Levému zaměřuje na literární i neliterární překlad) a vědecké metody obecně, kdy Levý (alespoň v publikaci Umění přkkladu) odmítal idealismus v teo- 
rii překladu a vítal její „uzemnění metodami lingvistickými. Do jisté míry tak - avšak víceméně zákonitě - u něj postrádáme postoj údivu, který je počátkem filozofického (a filozofujícího) myšlení, nepracuje ani s metodou paradoxu. Ilustrativně lze na tomto místě uvést výmluvnou zkratku G. Steinera, významného představitele hermeneutiky v oblasti překladu, když hovoří právě o problematice překladu: „Nemáme před sebou [př́rodní] vědu, ale exaktní umění (2010: 260). Jak známo, překlad je podle Levého uměním, které se snažil postihnout exaktními prostředky.

Při komparaci se dále ukázalo, že je na místě obezřetnost při výkladu některých tematických důrazů, jež uplatňují oba přístupy. Příkladem je aplikace teorie her u J. Levého. Zatímco hermeneutika si ji osvojila pro metaforické znázornění (dialogického) poměru mezi účastníky překladatelského procesu, Levý v ní naopak vidí možnost popsat vztahy mezi aktéry komunikačního procesu exaktními prostředky.

Pokud jde o procesualitu literárního dění a překladový proces, svým mimořádným zájmem něj a o proces vnímání Levý předznamenal kognitivní důraz, jenž se dnes prosazuje jako jedna $\mathrm{z}$ větví neohermeneutického přístupu v translatologii.

Vycházeje z pražského strukturalismu Levý v mnohém na své strukturalistické předchůdce navazuje. Některé jejich myšlenky, které - pokud by je rozvinul pro účely teorie překladu - by se konceptuálně blížily hermeneutickému přístupu, však opouští. Jedná se např́iklad o Mukařovského moment interakce mezi uměleckým dílem a jeho vnímatelem, pojem kolektivního vědomí apod. Skutečnost, že s nimi Levý dále nepracuje, může být dána bud' tlakem oficiální doktríny, která potlačovala idealismus, nebo Levého metodologickou důsledností, poprrípadě obojím. V druhém či třetím případě by uvedený odklon znamenal, že fundamentální otevřenost metodologie strukturalismu, na který navazoval, mu byla snad až př́liš dynamická. Ostatně ani Levému vlastní a pro něj tolik př́značná (a obdivuhodná) interdisciplinarita mu nedovolila integrovat metody, u nichž konstatoval, že se vymykají metodologii literární vědy (např. jeho ostych vůči psychologizujícímu rozboru - srov. výše).

Další oblastí, kde někteří jeho strukturalističtí předchůdci (zejména Mukařovský) byli „hermeneutičtější “ než Levý, je stěžejní otázka objektivity hodnoty děl. Pro Mukařovského je totiž objektivní estetická hodnota uměleckého díla něčím, co lze uvažovat jen potenciálně ${ }^{63}$. Naproti tomu Levý takovou objektivní hodnotu díla předkládá jako danost, o které (alespoň v díle Umění prekladu) nepochybuje. ${ }^{64}$

Levý dále zjevně činí distinkci mezi (psychologickým) pojmem osobnosti a (epistemologickým/noetickým pojmem) subjektivity, přičemž první kategorii do své teorie integruje jako žádoucí, druhou však z metodologické pozice a priori obsazuje skeptickou charakteristikou (subjektivita v tomto pojetí je zdrojem chybných interpretačních postupů, je potřeba se jí vyvarovat). Levého překladatel je tak součástí kolektivity, kde sice jde o dialektický vztah prvku a celku, ale interpretace na straně překladatele je podřízena objektivní ideji díla a je dána převládající dobovou ideologií. Naproti tomu v hermeneutice subjektivita (jako noetický pojem) znamená zdroj inspirativních podnětů (jež je však pochopitelně potřeba podrobit eventuální korekci) a interpretační stanovisko není svázáno snad vůbec žádnými objektivními (mimo jedince stojícími) aspekty; vychází pouze

63 Srov. heslo „Objektivní estetická hodnota daná artefaktem; její potenciální ráz“ in Grygar 1999: 161.

64 „[P]ři vnímání funguje text jako objektivní materiál“ (s. 48n). 
z pocitu „Stimmigkeit“, tedy jakéhosi vnitřního náhledu platnosti a správnosti. Vysvětlení tohoto rozdílu v přístupu k problematice (svobody recipienta ${ }^{65} \mathrm{a}$ ) interpretace se však i zde ukazuje jako primárně metodologické, protože Levý vnímá tento (pro hermeneutiku stěžejní) termín odlišně: Nesnaží se postihnout všechny odstíny a typy interpretace, ale předně interpretaci vědeckou (srov. Levý 1971: 17). Uzavřeme, že Levý má nepochybně blíže k objektivistické tradici v hermeneutice než k její subjektivistické tradici. ${ }^{66}$

S ohledem na další vývoj (post-)strukturalismu a jeho větší zohlednění lidského faktoru uvádí E. Tabakowska: „Uznání významu ,lidského faktoru“ vneslo do translatologie předpoklad subjektivity překladatele: Překladateli tak bylo dopřáno právo na vlastní identitu, díky čemuž bylo možné připustit, že objektivismus je jen mýtus, který usnadňuje život vědeckým pracovníkům“ (2015: 13, překlad T. S.). Toto stanovisko pochopitelně neprriléhá na Levého, protože jednak jeho vědecká tvorba byla regulována převládající dobovou ideologií a jednak si Levý objektivní hranice své interdisciplinarity kladl sám, svým důsledným trváním na exaktních metodách práce.

\section{Konkrétní termíny/pojmy}

Sledujeme-li průnik Levého díla s terminologií, a zejména obsahy hermeneutického přístupu v translatologii, některé pojmy vykazují veskrze úplný průnik, jiné průnik dílčí a některé pak se podstatně rozcházejí.

Úplný či převážný průnik se projevil u následujících pojmů z oblasti teorie překladu, literární teorie a dalších oblastí: nadsumativita, Levého pojetí vnímání a hermeneutický kruh, požadavek racionální kontroly nad nereflektovanou subjektivitou, pojem i požadavek kreativity překladatele a i dalších dispozic (nadání), nápadný průnik nacházíme mezi pojmy rovnost uměleckého účinku (Levý) a rovnosti ozvuku (rezonance) (Paepcke).

U Levého naopak nenacházíme pojem vzájemnosti mezi textem/dílem a recipientem a jen velmi málo pojednává o intuici, což jsou pojmy naopak významné pro hermeneutiku.

Avšak i některé aspekty potenciálního pozdějšího průniku (např. neracionální a subjektivní aspekty literárního - a předpokládejme i překladatelského - procesu) Levý nepochybně reflektoval - vždyt byl sám překladatelem a překlad též vyučoval, tudíž jistě v této oblasti nepostrádal ani osobní zkušenost ani zkušenost zprostředkovanou -, ale nehodlal je blíže rozebírat z metodologických důvodů, a to proto, že tak tehdy ještě nebylo možné činit exaktními metodami. Vzhledem k tomu, že dnešní kognitivní lingvistika, popř́ípadě tzv. kognitivní translatologie (včetně průniku mezi kognitivní lingvistikou a hermeneutickým př́stupem v překladu) již využití exaktních metod umožňují, lze snad poněkud spekulativně předpokládat, že by se Levý patrně zajímal o metodologické rozšíření vědy o překladu směrem k exaktním postupům kognitivního zkoumání rozhodovacího procesu a průnik obou př́istupů by se ještě zvětšil.

65 Stolzeová (1992) dokonce svobodě překladatele věnuje samostatný pododdíl - Aspekt svobody, s. 23.

66 Srov. rozlišení subjektivistické a objektivistické tradice, in Link 1980: 114. Podle Linkové (tamt., s. 122) tyto tradice existují paralelně vedle sebe, ale zároveň i v protikladném vztahu. K objektivistické tradici bychom z německých představitelů hermeneutiky mohli přiřadit např. R. Stolzeovou, k subjektivistickému proudu pak F. Paepckeho. 


\section{Závěr}

Tento text je především osobní poklonou před člověkem Jiřím Levým, který toho tolik zvládl, věděl a tušil. Navíc byl nucen tvořit v době nesvobody a komunistické deformace lidských myslí a charakterů, jíž však navzdory obdivuhodně obstál.

Abych tedy odpověděl na otázku po vztahu Levého, jeho díla a hermeneutiky, položenou v úvodu: Jiří Levý nemůže být považován za představitele neohermeneutického př́stupu v translatologii, a to s ohledem na chronologii: Neohermeneutický proud se v teorii překladu začal prosazovat až na konci 70. let 20. století, tedy cca 10 let po smrti Jiřího Levého (1967). Nejspíše jej nelze označit ani za (přímého) předchůdce (ve smyslu anglického ,predecessor $\left.{ }^{`}\right)$ neohermeneutického směru v translatologii, můžeme jej však označit za teoretika překladu, který (ve smyslu anglického ,precursor') předznamenal určité pojmy a postupy neohermeneutického myšlení o př̀kladu.

Jak uvádí Josef Hrabák v doslovu k publikaci Bude literární věda exaktní vědou?, teoretické dílo Jiřího Levého „končí otazníkem“. A je to právě tato tázavost, ale i celková otevřenost Levého myšlení, vtělená do jeho díla, jež otevírá prostor pro širokou recepci a interpretaci. Dílo Jiřího Levého je možné číst hermeneuticky a zůstává tak mimořádně inspirativní.

\section{BIBLIOGRAFIE}

Boncza Bukowski, Piotr, Heydel, Magda (2015) 'Polish studies in translation: Re-mapping an interdisciplinary field', in J. Králová, D. Mraček, S. Rubáš (eds.) Acta Universitatis Carolinae: Philologica 3/2015 - Translatologica Pragensia IX, Prague: Karolinum, 39-54.

Doležel, Lubomír (2000) 'Poststructuralism: A View from Charles Bridge', Poetics Today 21(4): 633-652.

Gadamer, Hans-Georg (1977) Die Aktualität des Schönen: Kunst als Spiel, Symbol und Fest, Stuttgart: Reclam.

Grygar, Mojmír (1999) Terminologický slovník českého strukturalismu, Brno: Host.

Hatim, Basil, Jeremy, Munday (2004) Translation: An advanced resource book, Abingdon: Routledge.

Holý, Jiři (2001) 'Poznámky ke koncepcím „Kostnické školy“ a českého strukturalismu', in M. Sedmidubský, M. Červenka, I. Vízdalová (eds.) Čtenář jako výzva. Výbor prací z kostnické školy recepční estetiky, Brno: Host, 271-308.

Hroch, Jaroslav (2006) 'K filozoficko-historickým aspektům vztahu českého strukturalismu a hermeneutického myšlení, in Ondřej Sládek (ed.) Český strukturalismus po poststrukturalismu, Brno: Host.

Chvatík, Květoslav (2001) Strukturální estetika, Brno: Host.

Jauß, Hans Robert (1979) 'Literaturgeschichte als Provokation der Literaturwissenschaft', in R. Warning (ed.) Rezeptionsästhetik, München: Fink, 126-162.

Jettmarová, Zuzana (2008) 'Czech and Slovak Translation Theories: the Lesser-known Tradition', in Jana Králová, Zuzana Jettmarová (eds.) Tradition versus Modernity. From the classic period of the Prague School to Translation Studies in the beginning of the 21st century, Prague: Charles University in Prague, Faculty of Arts/Togga, 15-46.

Jettmarová, Zuzana (2014) '20th Century Czech \& Slovak Theories and Western Turns', in Z. Jettmarová, Mozaiky překladu - Translation Mosaics. K devadesátému výročí narození Jiřího Levého (2016), Prague: Karolinum, 168-178.

Jettmarová, Zuzana (2016) Mozaiky překladu - Translation Mosaics. K devadesátému výročí narození Jiřího Levého, Prague: Karolinum.

Kloepper, Rolf (1967) Die Theorie der literarischen Übersetzung, München: Wilhelm Fink Verlag. 
Králová, Jana, Jettmarová, Zuzana (2008) 'Introduction’, in Jana Králová, Zuzana Jettmarová (eds.) Tradition versus Modernity. From the classic period of the Prague School to Translation Studies in the beginning of the 21st century. Prague: Charles University in Prague, Faculty of Arts/Togga, 9-14.

Králová, Jana, Mraček, David, Rubáš, Stanislav (eds.) Acta Universitatis Carolinae: Philologica 3/2015 Translatologica Pragensia IX, Prague: Karolinum.

Králová, Jana, Svoboda, Tomáš (2016) 'Jiří Levý en el contexto de la investigación de la época y en la actualidad', Mutatis mutandis 9(2): 205-223.

Krysztofiak, Maria (2013) Einführung in die Übersetzungskultur, Frankfurt am Main: Peter Lang.

Levý, Jiř́ (1971) Bude literární věda exaktni vědou?, Prague: Československý spisovatel.

Levý, Jiří (1996) České teorie překladu I: Vývoj překladatelských teorií a metod v české literatuře, 2. ed., Prague: Ivo Železný.

Levý, Jiř́ (1998) Umění prekladu, Prague: Ivo Železný.

Levý, Jiří (2011) The Art of Translation, transl. by Patrick Corness, ed. by Zuzana Jettmarová, Amsterdam \& Philadelphia: John Benjamins.

Link, Hannelore (1980) Rezeptionsforschung. Eine Einführung in Methoden und Probleme, 2. ed., Stuttgart, Berlin, Köln, Mainz: W. Kohlhammer Verlag.

Mukařovský, Jan (1936) 'Estetická funkce, norma a hodnota jako sociální fakty', in Studie z estetiky (1966), Prague: Odeon.

Nord, Christiane (1995) Textanalyse und Übersetzen: Theoretische Grundlagen, Methode und didaktische Anwendung einer übersetzungsrelevanten Textanalyse; Heidelberg: Julius Groos Verlag, 3. Aufl.

Paepcke, Fritz (1968) 'Verstehen und Übersetzen', in Linguistica Antverpiensia II, Rijksuniversitair Centrum Antwerpen, Hoger instituut voor vertalers en tolken, 329-351; in Paepcke (1986), 56-71.

Paepcke, Fritz (1971) 'Sprach-, text- und sachgemäßes Übersetzen. Ein Thesenentwurf', in Wilss, W. (ed.) Übersetzungswissenschaft (1981), Darmstadt: Wissenschaftliche Buchgesellschaft, 112-119.

Paepcke, Fritz (1979) 'Übersetzen als Hermeneutik', in Peter Lutz Lehmann, Robert Wolff (eds.) Das Stefan-George-Seminar 1978 in Bingen am Rhein: Eine Dokumentation, Heidelberg: Verlag Rabe, 96-114; in Paepcke (1986), 102-120.

Paepcke, Fritz (1981) 'Übersetzen zwischen Regel und Spiel', in Mitteilungsblatt für Dolmetscher und Übersetzer (MDÜ) 27(1): 2-7; in Paepcke (1986), 121-134.

Paepcke, Fritz (1985) 'Textverstehen - Textübersetzen - Übersetzungskritik', in Mitteilungsblatt für Dolmetscher und Übersetzer (MDÜ) 35(1): 1-11; in Paepcke (1986), 158-175.

Paepcke, Fritz (1986) Im Übersetzen leben, Tübingen: Gunter Narr Verlag.

Pechar, Jiří (2003) 'Hermeneutika v minulosti a dnes', Literární noviny, 22. 12. 2003.

Prunč, Erich (2001) Einführung in die Translationswissenschaft, Vol. 1, Graz: Institut für Theoretische und Angewandte Translationswissenschaft.

Ricœur, Paul (1969) Le conflit des interprétations, Paris: Éditions du Seuil.

Sedmidubský, Miloš, Červenka, Miroslav, Vízdalová, Ivana (eds.) (2001) Čtenář jako výzva: výbor z prací kostnické školy recepčni estetiky, 1. ed., Brno: Host.

Schippel, Larisa (2016) 'Translation as Estrangement: Andrei Fedorov and the Russian Formalists', in Larisa Schippel, Cornelia Zwischenberger (eds.) Going East: Discovering New and Alternative Traditions in Translation Studies, Frank \& Timme GmbH, 247-267.

Schneider, Jan (2006) ‘Český strukturalismus a/versus interpretace', in Ondřej Sládek (ed.) Český strukturalismus po poststrukturalismu, Brno: Host 2006.

Schultze, Brigitte (2015) 'Jiří Levýs contribution to translation studies as represented in the De Gruyter Encyclopedia Übersetzung, Translation, Traduction', in J. Králová, D. Mraček, S. Rubáš (eds.) Acta Universitatis Carolinae: Philologica 3/2015 - Translatologica Pragensia IX, Prague: Karolinum, 27-38.

Snell-Hornby, Mary (2006) The Turns of Translation Studies: New paradigms or shifting viewpoints?, Amsterdam/Philadelphia: John Benjamins Publishing.

Steiner, George (1975) (2010) Po Bábelu: Otázky jazyka a překladu, Praha: Triáda.

Stierle, Karlheinz (1975) 'Was heisst Rezeption bei fiktionalen Texten', Poetica 7: 345-387; zde cit. dle překladu 'Co je recepce u fikcionálních textů’ in M. Sedmidubský, M. Červenka, I. Vízdalová (2001), $199-242$.

Stolze, Radegundis (1992) Hermeneutisches Übersetzen. Linguistische Kategorien des Verstehens und Formulierens beim Übersetzen, Tübingen: Gunter Narr Verlag. 
Stolze, Radegundis (2010) 'Hermeneutics and translation', in Yves Gambier, Luc van Doorslaer (eds.) Handbook of translation studies, Amsterdam: John Benjamins, 141-146.

Stolze, Radegundis (2011) Übersetzungstheorien. Eine Einführung, Tübingen: Gunter Narr Verlag.

Striedter, Jurij (1989) 'Czech Structuralism and the Present Debate about Aesthetical Value', in Jurij Striedter, Literary Structure, Evolution, and Value: Russian Formalism and Czech Structuralism Reconsidered, Cambridge, MA: Harvard University Press, 155-262; zde cit. dle př̌ekladu 'Český strukturalismus a současná diskuse o estetické hodnotě, in M. Sedmidubský, M. Červenka, I. Vízdalová (2001), 101-198.

Suchomel, Milan (2017) Př́spěvek na konferenci Ad translationem: Pocta Jiřímu Levému. 26.-27. říjen 2017, Masaryk University, Brno, nepublikovaný handout z konference.

Svoboda, Tomáš (2004) 'Procesualita literárního překladu', in Petr Pořízka and Vladimír Polách (eds.) Vztah langue a parole v perspektivě ,interaktivního obratu“ v lingvistickém zkoumání, Olomouc: Univerzita Palackého v Olomouci, 312-315.

Špirk, Jaroslav (2016) 'Czechoslovak Translation Studies: Depreciated Legacy or Inspiration for Today?', in Larisa Schippel, Cornelia Zwischenberger (eds.) Going East: Discovering New and Alternative Traditions in Translation Studies: Frank \& Timme GmbH, 77-98.

Tabakowska, Elżbieta (2015) 'Translation Studies meets linguistics: Pre-structuralism, structuralism, post-structuralism', in J. Králová, D. Mraček, S. Rubáš (eds.) Acta Universitatis Carolinae: Philologica 3/2015 - Translatologica Pragensia IX, Prague: Karolinum, 7-18.

Wilss, Wolfram (ed.) (1981) Übersetzungswissenschaft. Darmstadt: Wissenschaftliche Buchgesellschaft.

Wutsdorff, Irina (2006) 'Eine Suche nach den Möglichkeiten der Interpretation zwischen Strukturalismus und Hermeneutik', Kritické rozhledy (3)5.

\section{RESÜMEE}

Auf den ersten Blick zeigen die Werke des wichtigsten tschechischen Theoretikers innerhalb der Übersetzungswissenschaft des 20. Jahrhunderts und eines der Pioniere der selbstständigen Übersetzungswissenschaft überhaupt, Jiří Levý (1926-1967), viele Ähnlichkeiten mit den Gedanken und den Anhaltspunkten des späteren (neo)hermeneutischen Ansatzes innerhalb der Translatologie. Diese Meinung wird gelegentlich vertreten, und zwar auch im Rahmen des wissenschaftlichen Diskurses. Schon auf den zweiten Blick lässt sich jedoch eine Reihe von Diskrepanzen zwischen den beiden wissenschaftlichen Ansätzen feststellen, von denen einige Verschiedenheiten substantieller Art sind. Jiř́ Levý lässt sich kaum als eigentliches Mitglied des neohermeneutischen Ansatzes in der Translatologie ansehen, und zwar schon aufgrund der Chronologie: Er starb etwa 10 Jahre vor der Etablierung dieses wissenschaftlichen Zweiges, zu der es in den späten 70er und frühen 80er Jahren des 20. Jahrhunderts kam.

Beim Vergleich einiger seiner Ansätze mit denen des hermeneutischen Ideengutes ergibt sich folgendes Bild: Es gibt Fälle, in denen sich die Konzepte fast perfekt entsprechen, es gibt aber auch solche, die sich stark unterscheiden, und schließlich eine Grauzone dazwischen.

Neben einem spezifischen methodischen Merkmal - dass eben die beiden Ansätze umfangreiche Beispiele verwenden, um ihre theoretischen Ansichten zu verdeutlichen - gibt es Begriffe und Auffassungen der Übersetzungswissenschaft und Literaturtheorie, deren Inhalt von beiden geteilt wird. Hierher gehören die folgenden Termini und Ideen: Die sog. Übersummativität von Texten (ein Text als Ganzes ist mehr als die einfache Addition seiner Bestandteile), Levýs Auffassung der Wahrnehmung einerseits und der hermeneutische Zirkel andererseits, Kreativität und die anderen, bei einem Übersetzer vorauszusetzenden Eigenschaften, sowie die Äquivalenz der ästhetischen Wirkung. Die beiden Ansätze (der von Levý und jener der Hermeneutik) weisen eine teilweise Überlappung auf, was die Anwendbarkeit der Übersetzungstheorie sowie die Sprache und den Stil ihrer theoretischen Werke betrifft, sie stellen die Person des Empfängers/Übersetzers in den Vordergrund usw. Dennoch gibt es auch Unterschiede, vor allem, was die allgemeine thematische Ausrichtung betrifft (die Hermeneutik setzt sich sowohl mit dem Thema der literarischen als auch mit jenem der Fachübersetzung auseinander, während sich Levý ausschließlich auf literarische Übersetzung konzentrierte), aber auch die Methode der wissenschaftlichen Arbeit im Allgemeinen ist verschieden: Levý hat (zumindest in seinem Werk Die literarische Überset- 
zung - Theorie einer Kunstgattung), anders als die Hermeneutik, im Rahmen seiner wissenschaftlichen Methode, die er sich möglichst exakt und objektiv wünschte, stets Themen gemieden, die mit dem Idealismus in Zusammenhang stehen.

Ansonsten würde man, was einige der übersetzungswissenschaftlich relevanten Schwerpunkte angeht, in Levýs Werken kaum die Auffassung einer persönlichen Beziehung zwischen Text und seinem Empfänger finden, die wiederum für die Hermeneutik typisch ist; darüber hinaus ist bei Levý auch der Begriff der Interpretation, sowie jener der Subjektivität unterschiedlich. Allerdings trifft zu, dass Levý auch weitere Aspekte einer eventuellen Überschneidung der beiden Ansätze reflektierte (z.B. nicht rationale und subjektive Aspekte des literarischen/übersetzerischen Prozesses), er weigerte sich jedoch, diese detailliert zu behandeln, da es der Wissenschaft zu seinen Lebzeiten an exakten Methoden fehlte, mit denen man solche Phänomene hätte erforschen können, und spekulativ wollte Levý in seiner Theorie nicht werden.

Zusammenfassend kann festgehalten werden, dass das Werk von Jiří Levý natürlich ,hermeneutisch gelesen' werden kann. Anstatt jedoch Levý für einen (direkten) Vorgänger (im Sinne des englischen predecessor) zu halten, ist es wohl eher angebracht, ihn als Vorläufer (precursor) der hermeneutischen Herangehensweise innerhalb der Translatologie anzusehen, wobei seine Theorie weiterhin in ihrer Offenheit und Dynamik höchst relevant und äußerst inspirierend ist und bleibt.

PhDr. et Bc. Tomáš Svoboda, Ph.D.

Ústav translatologie, Filozofická fakulta Univerzity Karlovy, Praha

tomas.svoboda@ff.cuni.cz 